\title{
MATERIALY
}

Iwona H. Pugacewicz

Warszawa

\section{Organizacja i plany wobec Biblioteki Wersalskiej w świetle wybranych relacji i źródłowych}

Po upadku powstania listopadowego rozpoczęto proces systematycznej likwidacji polskich instytucji oświatowo-naukowych na Litwie, a funkcjonujące przy nich biblioteki i zbiory muzealne wywożono przeważnie do Petersburga. Wobec tych posunięć, wczesnym latem 1841 r., wychodźcy polscy we Francji - z myślą o przyszłym powrocie do ojczyzny oraz jako protest przeciw rządom bezwzględnego gubernatora Michała Murawjewa (późniejszego osławionego „Wieszatiela”), który w bezpardonowy sposób okradł uniwersytet wileński i inne polskie instytucje kultury, a także w celu zapewnienia sobie kontaktu z polską kulturą i literaturą - zawiązali Stowarzyszenie Biblioteki Wileńskiej. Na czele tej inicjatywy stanęli wojewoda Antoni Ostrowski, poseł Antoni Przeciszewski, Ksawery Godebski i Hipolit Klimaszewski. Emigranci liczyli na to, że w niedalekiej przyszłości, jak tylko uda się wyzwolić ojczyznę, wszystkie uratowane i zgromadzone za granicą precjoza, na czele z książkami, zostaną przekazane Akademii Wileńskiej. W powstałej na obczyźnie prowizorycznej, bo założonej w prywatnych pomieszczeniach mieszkalnych wojewody Ostrowskiego, Bibliotece Wersalskiej deponowano nie tylko osobiste kolekcje przywożone z kraju lub skupowane na emigracji, na czele z dubletami z bogatego zbioru samych Ostrowskich, ale zbierano też wszelkie cenne pamiątki narodowe o znacznej wartości historyczno-muzealnej. 
Krótka, bo zaledwie kilkuletnia, historia Biblioteki Wersalskiej, która nadal oczekuje swojej monografii, stanowi niezwykle interesujący przyczynek do dziejów emigracyjnego bibliotekarstwa. Oto w niecałe półtora roku po uroczystym otwarciu jednej, wspólnej książnicy polskiej w Paryżu, scalonej ze zbiorów Towarzystwa Literackiego, Wydziału Historycznego, Wydziału Statystycznego oraz Towarzystwa Pomocy Naukowej $^{1}$, wyłamujący się z powyższej akcji wojewoda Antoni Ostrowski podpisał w dniu 9 czerwca $1841 \mathrm{r}$. protokół utworzenia odrębnej biblioteki emigracyjnej w Wersalu. Na opiekunów tak powstałej nieopodal tej paryskiej, ale bardziej podkreślającej swoją demokratyczną proweniencje biblioteki, powołano:

... znanych z zasług patriotów:

1* Władysława Ostrowskiego Marszałka Sejmu rewol[ucyjnego].

2* Joachima Lelewela, b. czlonka Rządu Nar[odowego].

3* Poslów: Biernackiego Alojzego.

4*Tyszkiewicza Wincentego.

$5^{*}$ Antoniego Hluszniewicza.

6* Xawerego Godebskiego.

$7^{*}$ Ant. Przeciszewskiego.

Jako też Rodaków:

8* Leonarda Chodzkę.

9* E. Staniewicza

zostawując zaproszenie większej liczby Opiekunów tak czynnych jak honorowych (jeśliby się tego okazała potrzeba) do chwili, w której opieka ukonstytuowana zostanie $^{2}$.

Nawet pobieżny przegląd życiorysów mężów podpisanych pod aktem utworzenia wersalskiej książnicy, wskazuje na ich zdecydowanie większe zaangażowanie po lewej stronie sceny politycznej ówczesnej emigracji. Na naczelnego konserwatora biblioteki powołano Hipolita Klimaszew-

${ }^{1}$ Biblioteka Polska w Paryżu, powstała z inicjatywy Juliana Ursyna Niemcewicza i emigracji skupionej wokół Hotelu Lambert, została uroczyście otwarta w niedzielę 24 marca 1839 r. W uroczystości, która miała miejsce w domu pod numerem 32 - mieszkaniu kasztelana Ludwika Platera, przy ulicy de Londres, uczestniczyło ok. trzydziestu Polaków. Zob. Cz. Chowaniec, Karol Sienkiewicz i jego dzieło, [maszynopis], Biblioteka Polska w Paryżu (dalej: BPP), rkps 351, Archiwum rodzinne Sienkiewiczów, t. 4 (materiał udostępniony przez K. Serokę).

${ }^{2}$ Wiadomości o Bibliotece Polskiej $w$ Wersalu 1841, Cena ksiegarska cent. 25., Przedaje się w Paryżu w księgarni Polskiej, rue de l'Echaudé, 9, $w$ Wersalu w drukarni Klefera, Place d'Armes, 17, s. 4 (BPP, akc. 2332, t. 1.a): Biblioteka Polska w Wersalu 1841-42. 
skiego $^{3}$, przyszłego dyrektora polskiej szkoły w Paryżu. Większość z opiekunów, których nazwiska widnieją w dokumencie wersalskim, w niedalekiej przyszłości odda się działalności społecznikowskiej na rzecz Szkoły Narodowej Polskiej na Batignolles i tamtejszej książnicy, do której ostateczne w 1855 r. zostaną przeniesione zbiory po opisywanej tu, a zlikwidowanej w 1843 r. Bibliotece Wersalskiej ${ }^{4}$.

Powracając do jej początków, warto zwrócić uwagę, za Januszem Pezdą, autorem „finansowej biografii” ks. Adama Jerzego Czartoryskiego ${ }^{5}$ oraz za Elżbietą Z. Wichrowską, która z kolei opracowała „biografię literacką" Hipolita Klimaszewskiego ${ }^{6}$, że być może jedną z przyczyn powołania przez A. Ostrowskiego odrębnej od tej paryskiej, sygnowanej nazwiskiem jej założyciela, biblioteki w Wersalu był fakt nieporozumienia z Hotelem Lambert - niemożności przeforsowania idei wyodrębnienia z całości właśnie tworzącej się w Paryżu biblioteki, odrębnego księgozbioru sygnowanego nazwiskiem Ostrowskich herbu Rawicz ${ }^{7}$.

Biblioteka Wersalska istniała niespełna trzy lata. W 1843 r. została przeniesiona, a de facto zlikwidowana, wraz z przeprowadzką jej twórcy Antoniego Ostrowskiego oraz jej głównego organizatora H. Klimaszewskiego, do Les Maderek pod Tours.

Gdy w 1845 r. zmarł wojewoda Ostrowski ${ }^{8}$, rozpoczęła się dyskusja o dalszych losach jego biblioteki. Najważniejszy glos w niej należał do H. Klimaszewskiego, ówczesnego dyrektora polskiej szkoły w Paryżu, dawnego korepetytora synów Ostrowskiego i jego najbliższego wspó1pracownika, a także przyjaciela.

Po trwających z górą trzy lata negocjacjach, spakowane w skrzynie zbiory przewieziono ostatecznie do Paryża, ale nie do książnicy spod znaku Czartoryskich, lecz do tej na bulwarze Batignolles 46. Szkolny księgozbiór powiększył się w ten sposób o 4000 książek i różnych broszur. Był to pierwszy tak duży emigracyjny dar, który znalazł przyjazne

${ }^{3}$ Związany z centrowym Zjednoczeniem Emigracji Polskiej, pełnił funkcje dyrektora polskiej szkoły w latach 1847-1853. Więcej, zob.: S. Konarski, Klimaszewski Hipolit (1802-1874), PSB, t. 12, s. 618-620.

${ }^{4}$ Na temat losów Biblioteki Batignolskiej, w tym również i tej Wersalskiej, zob.: I.H. Pugacewicz, Zmienne losy biblioteki szkolnej w Paryżu 1842-1963, [w:] Biblioteki w systemie kultury jednoczacej się Europy, red. M. Zając, E.B. Zybert, s. 11-28.

5 J. Pezda, Ludzie i pieniadze. Finanse $w$ dziatalności Adama Jerzego Czartoryskiego i jego obozu w latach 1831-1848, Kraków 2003, s. 204-205.

${ }^{6}$ E.Z.Wichrowska, Hipolit Klimaszewski - nieznana karta z dziejów Wielkiej Emigracji, Warszawa 2012, s. 89-97.

7 Tamże, s. 89.

${ }^{8}$ W. Zajewski, Ostrowski Antoni Jan (1782-1845), PSB, t. XXIV, s. 546-550. 
schronienie w murach polskiej szkoły. Za darowizną tą poszły inne ${ }^{9}$, znacznie podnosząc rangę Biblioteki Batignolskiej, która rozpoczęła ciche współzawodnictwo, ale, jak się później okazało, również i współpracę z tą najsłynniejszą, mieszczącą się pod numerem 6, quai d'Orléans w czwartej dzielnicy Paryża.

Poniżej prezentujemy trzy mało znane dokumenty obrazujące losy wersalskiej książnicy i snute wobec niej plany. Pierwszy dokument zaczerpnięty został z Wiadomości o Bibliotece Polskiej w Wersalu 1841. Jest to interesujący dziewięciopunktowy statut w formie uchwaty ukonstytuowania się opieki nad Biblioteka tułactwa polskiego na teraz $w$ Wersalu ${ }^{10}$.

Drugi z publikowanych dokumentów to spisane 1 styczna 1842 r. ręką Klimaszewskiego Uwiadomienie o założeniu biblioteki i zasadach korzystania z jej księgozbioru. Zachowały się dwa litografowane, jednokartkowe egzemplarze tego pisma: po jednym w zbiorach Biblioteki Narodowej oraz w Bibliotece Polskiej w Paryżu ${ }^{11}$.

Trzeci wydany dokument to artykuł polemiczny pióra H. Klimaszewskiego z 1842 r., zamieszczony w specjalnej broszurze poświęconej Bibliotece Polskiej w Wersalu, zatytułowany Sprostowanie kilku fatszów umieszczonych w 86 Nrze „Dziennika Narodowego” z powodu Biblioteki Polskiej $w$ Wersalu ${ }^{12}$. Obrazuje on w sposób niezwykle interesujący determinację środowiska wersalskiego w obronie swojej nowej biblioteki przed atakami politycznymi czartoryszczyków. Tekst, w całości poniżej zamieszczony, nie tylko ukazuje linię obrony stronników Ostrowskiego, ale też wskazuje na funkcjonalne aspekty pracy nowej emigracyjnej instytucji, odtwarzając przy okazji nowy romantyczno-oświeceniowy sposób rozumienia posługi obywatelskiej. Stanowi także ciekawy przyczynek do jakże interesującego, choć nadal przez nikogo nie podjętego tematu roli polemiki publicystycznej w dziejach Wielkiej Emigracji.

Poniższe teksty źródłowe wydano według zasad zawartych w pracy Ireneusza Ihnatowicza, Projekt instrukcji wydawniczej dla źródet historycznych XIX i początku XX wieku, „Studia Źródłoznawcze”, 1962, t. 7, s. $99-123$.

${ }^{9}$ Więcej na temat rozrostu Biblioteki Batignolskiej i jej swoistej rywalizacji z Biblioteką na Wyspie św. Ludwika zob. I.H. Pugacewicz, dz. cyt., s. $15 \mathrm{nn}$.

${ }^{10}$ Wiadomości o Bibliotece Polskiej w Wersalu 1841, s. 5-8.

${ }^{11}$ BPP, akc. 2332, t.1.a): Biblioteka Polska w Wersalu 1841-42. Na egzemplarz zachowany w BN (sygn. II 56.581), z pieczęcią Biblioteki Szkoły Polskiej na Batignolles, zwraca uwagę E.Z. Wichrowska, dz. cyt., s. 93.

12 BPP, akc. 2332, t.1.a): Biblioteka Polska w Wersalu 1841-42. 


\section{Dokument I \\ UCHWALA \\ UKONSTYTUOWANIA SIĘ OPIEKI \\ NAD BIBLIOTEKĄ TUŁACTWA POLSKIEGO \\ NA TERAZ W WERSALU}

Niżej podpisani, jako pierwsi Fundatorowie Biblioteki Tułactwa polskiego, na teraz w Wersalu, po wysłuchaniu protokołu z dnia 9 czerwca 1841 r. stwierdzonego podpisami Wojewody Antoniego Ostrowskiego, Posłów Antoniego Przeciszewskiego i Xawerego Godebskiego, jako niemniej tymczasowego Konserwatora Hippolyta Klimaszewskiego, przekonawszy się o rzetelności podań w nim wyszczególnionych, dających historyą zawiązku tej użytecznej ze wszechmiar Instytucji, powodowani przytem gorliwością o dalsze rozwijanie i uzupełnienie skreślonego planu, po wspólnem naradzeniu się i przyjęciu na się obowiązków chlubnego nad rzeczonym Zakładem Opiekuństwa, dla ubezpieczenia go na przyszłość, jako podzielać mającego rożne losów koleje, którym położenie tułacze podległem być może, postanowili i stanowią co następuję:

\section{ARTYKUŁ 1.}

Otwarta Kolekta składać mających Bibliotekę Tułactwa polskiego kontynuować się będzie i w latach następnych z wyraźnem i nieodmiennem onych przeznaczeniem na użytek publiczny rodziny tułaczej; po powrocie zaś do kraju, na wcielenie złożonego z nich księgozbioru, jako własności narodowej, do jednej z głównych Bibliotek oswobodzonej Polski, w czem pierwszeństwo przed innemi zawsze mieć będzie Biblioteka Akademii Wileńskiej.

\section{ARTYKUŁ 2.}

Warujemy i niniejszym zastrzegamy, iż Biblioteka Tułactwa polskiego z przeznaczeniem wyżej wyrażonem, nigdy, przez nikogo, i pod żadnym pozorem rozdzielaną na części, rozdrabnianą, a tem samem umniejszaną ani też odmienianą być nie może - sama tylko wymiana dubletów stosownie do instrukcji Konserwatorowi przez Opiekunów danej, miejsce mieć może.

\section{ARTYKUŁ 3.}

Wspomniona Biblioteka składać się będzie nie tylko z ksiąg drukowanych, rękopisów i aktów a nawet depozytów najmniej na pół roku doko- 
nanych, ale nadto zawierać może wszelkie przedmioty dotyczące pamiątek narodowych i obcych, tudzież numizmata i medale, mappy, karty geograficzne i wszelkie ryciny - przyjmować też będzie i zaopatrywać w różne modele machin nowością i użytkiem odznamienowan, ściągające się do sztuk pięknych, kunsztów, rzemiosł, rolnictwa itd., wespół z samemi dziełami sztuki; słowem: każdy dar jakiej bądźkolwiek natury naukowej, czy od Rodaka, czy od zamiłowanego w świętej sprawie polskiej cudzoziemca z wdzięcznością przyjęty, wiernie zapisany i przezornie przechowany, na użytek publiczny w celach wyżej pomienionych obróconym zostanie.

\section{ARTYKUŁ 4.}

Ogólne czuwanie nad dobrem i powodzeniem całego Zakładu będzie sprawą Opiekunów tak w kraju jak za granicami Onego przebywających; szczegółowy zarząd Onego porucza się pierwszemu Opiekunowi; dozór zaś i materialny porządek powierza się Konserwatorowi Biblioteki przez Opiekę mianowanemu, który zarazem jej Sekretarzem być może. W każdem zatem razie prędkiej decyzji wymagającym i w przedstawieniach potocznych przez Konserwatora czynionych, dobro zakładu na celu mających, pierwszy Opiekun osobiście stanowić i decydować może.

\section{ARTYKUŁ 5.}

Obowiązkiem Opiekunów jest: wzbogacać pośrednio lub bezpośrednio zakład, którym się opiekują; korzystać z nabytków nieprzewidzianych, jako tez zaopatrywać go według sił, możności i zdarzeń przyjaznych, w przedmioty artykułem trzecim objęte.

ARTYKUŁ 6.

Opiekunowie w liczbie jak największej zebrani przepiszą wewnętrzną organizacją Biblioteki; ułożą instrukcją dla jej Konserwatora; wskażą sposób w jakowy chcą z ksiąg korzystać, do używania onych przypuszczeni być mogą; dopełnią oraz wszystkiego, co uznają zgodnem i z naturą położenia swego i z głównemi zasadami w dniu dzisiejszym uchwalonemi.

\section{ARTYKUŁ 7.}

Niżej podpisani Opiekunowie czynni zapraszają Wojewodę Antoniego Ostrowskiego, na pierwszego Opiekuna, którego attrybucyą jest:

a) Możność zapraszania Rodaków na Opiekunów czynnych, jako też na honorowych, tych przyjaciół naszych cudzoziemców $\left({ }^{*}\right)$, których uzna 
za mogących być moralnie lub materialnie użytecznymi pomienionemu Zakładowi.

b) Bezpieczne ulokowanie wszystkich zbiorów składających i składać mających rzeczoną Bibliotekę, w miejscu najbliższem swego pobytu, jako też przeniesienie onych w inne miejsce, gdyby się tego jakowa przezwana ukazała potrzeba.

c) Wynachodzenie i przyjmowanie wszelkiej natury funduszów, oraz użycie onych na potrzeby Biblioteki z wykazem przychodu i rozchodu na corocznem zebraniu opiekunów.

d) Zwiększanie i przechowywanie tego najdroższego skarbu przyczynić się mogącego do upowszechnienia pomiędzy wszystkimi ojczyzny naszej mieszkańcami, tyle pożądanej oświaty prowadzącej do fizycznej i umysłowej Swobody.

e) Mianowanie zastępcy w przypadku dymissyi lub śmierci aktualnego konserwatora.

\section{ARTYKUŁ 8.}

Ciż Opiekunowie powołują na Konserwatora Biblioteki Rodaka Hipolita Klimaszewskiego b. Profesora Szkół Wileńskich, którego zarazem Sekretarzem swym mianują. Obowiązkiem też jego będzie w razie śmierci pierwszego Opiekuna, uwiadomić i zaprosić Opiekunów do nowego wyboru.

\section{ARTYKUŁ 9.}

Oprócz corocznego zbierania się Opiekunów w dniu pamiętnym dla obecnych i następnych pokoleń polskich, w dniu będącym data Ukazu zrabowania Bibliotek Narodowych; nadzwyczajne Zgromadzenie zwołać może pierwszy Opiekun, na własne lub trzech czynnych Opiekunów żądanie.

Ograniczając wykazanemi artykułami czynności swoje na teraz, niniejszą Uchwałę stanowimy i podpisami własnoręcznemi stwierdzamy.

Dzialo się w Wersalu (Versaille, Seine-et-Oise) przy boulevard de la Reine, 121.

D. 13 czerwca $1841 \mathrm{r}$.

Podpisano
A. Biernacki
Wincenty Tyszkiewicz
Xawery Godebski
Antoni Hłuszniewicz 
Antoni Przeciszewski

Wojewoda A. Ostrowski, Jenerał b. Dow. Gwardii Nar. warszawskiej.

Leonard Chodźko

Sekretarz i Konserwator Biblioteki, H. Klimaszewski

Za zgodność z Aktami Biblioteki, świadczę

Sekretarz H. Klimaszewski

(*) Oddzielnie dla cudzoziemców otwartą zostanie księga złota (un livre d'or), w którą ku wiecznej pamięci wpisywane będą imiona dawców dowodzących swej życzliwości dla Polaków.

\section{Dokument II}

\section{UWIADOMIENIE}

Biblioteka Polska w Wersalu obecnie składająca się przeszło z 1200 woluminów szczególnie [utwory] z polskiej podróży, prawodawstwa i sztuki wojskowej dotyczących, każdemu z Rodaków zamieszkałych w temże mieście i wszystkim korzystać z niej chcącym przystępna jest codziennie, wyjąwszy Niedziele i święta, w godzinach przedpołudniowych.

Z małym wyjątkiem obejmującym Atlasy i Rękopisma, inne dzieła w skład jej wchodzące, jako własność publiczna, za rewersem gwarantującym ich całość i zwrot w terminie na 6 do 10 dni dawane będą aż do chwili, w której ostateczna Organizacya dopełnioną i za powiększeniem się Funduszów Czytelnia przy niej otworzoną zostanie. Dzienniki i ulotne publikacje nazajutrz po wzięciu zwracane być mają. Skrócony Katalog wkrótce ogłoszonym będzie. Zgłoszenia się listowne frankowane być powinny. Adres Biblioteki polskiej w Wersalu rue de Jouvencel, 2.

d. 1. Stycznia $1842 \mathrm{r}$.

H. Klimaszewski

konserwator Bibl. Pol. w Wersalu 
Dokument III

\section{SPROSTOWANIE KILKU FAŁSZÓW \\ UMIESZCZONYCH W 86 Nrze DZIENNIKA NARODOWEGO Z POWODU \\ Biblioteki Polskiej w Wersalu}

Redaktorowie Dziennika Narodowego zdając sprawę publiczności z Zakładów Naukowych i dobroczynnych, z kolei umieścili słów kilka o Bibliotece Polskiej w Wersalu, a raczej epigram wymierzony szczególnie przeciw imionom, którym Zakład ten początek swój winien. Nie idzie tu o obronę znakomitego Obywatela znanego w Kraju i w Emigracji równie z patriotyzmu, jak z cnót publicznych prywatnych - bowiem wyższym on jest nad pochwały lub nagany jakie PP. Redaktorowie tegoż dziennika skierować doń mogą - nie idzie równie o ich sympatye lub antypatie dla samego Zakładu Biblioteki, której oni, jak widać, ani pomóc ani zaszkodzić są zdolni - idzie tu przede wszystkiem o wyświecenie rzetelnego stanu pomienionej Instytucyi mylnie przez PP. Redaktorów pojętej i przedstawionej, a tem samem o wykazanie czytającej publiczności fałszów, które jej na periodyczny pokarm, w 86 numerze posłał Dziennik Narodowy. Z tytułu więc konserwatora Biblioteki Polskiej w Wersalu, i wytacznie od siebie uznaję za potrzebę przemówić tych słów kilka, nim obszerniejsze sprawozdanie poda sposobność opinii publicznej przesądzić sądy dziennikarskie.

Podana wiadomość o założeniu Biblioteki Polskiej w Wersalu, z wykazaniem jej początku tworzenia się i głównej myśli rozwijaniu się jej przewodniczącej, mile przyjętą została równie w Kraju jak w Emigracyi, na co dziś już liczne w Aktach tego zakładu znajdują się dowody, które w swojem miejscu i czasie staną się własnością publiczną. Wkrótce też po ukonstytuowaniu się właściwego nad tą Instytucją zarządu, staraniem opiekunów zaczęła się ona wzbogacać w dzieła wyższej wartości naukowej tak z dawnych jako też z najnowszej epoki; w atlasy i mappy topograficzne; nadto w dzienniki i innej natury pisma. Jedno z najpierwszych miejsc, co do ofiar, zajmują przychylni sprawie polskiej cudzoziemcy, którzy wolniejsi od zawiści zagnieżdżonej w sercu niektórych z naszych współbraci, na pierwszą wiadomość tworzenia się tego Zakładu, pospieszyli z darami niepośledniej ceny wewnętrznej, a nadto i moralnie i materialnie w przyszłości wspierać ja przyrzekli. Nim skrócony katalog dary te szczegółowie wykaże, nieobojętną może będzie rzeczą dla Rodaków dowiedzieć się, iż w rzędzie pierwszych dla niej subskryptorów jest 
Rząd francuski - i tak:

Ministeryum Oświecenia przysłało w r. $1841 \quad$ tomów 45

$\begin{array}{lll}\text { Ministeryum Marynarki, dzieł i atlasów tomów } 20 & 20\end{array}$

Ministeryum Wojny, ditto tomów 29

Z upewnieniem, iż przy końcu każdego roku, taką lub podobną ilość dzieł najnowszych, uznanych za najlepsze, do Biblioteki Polskiej w Wersalu zaofiarują.

Pomiędzy przyjaciółmi tejże Instytucyi możemy tu wymienić kilku; jako to:

PP. Treuenthal, profesor w Saint-Cyr ofiarował tomów 30

Pułkownik Henry Anglik $\quad 30$

Remilly, Deputowany i Maire ${ }^{13}$ wersalski $\quad 180$

Pułkownik Zeltner, złożył w niej 359

C de Lasteyrie, wniósł do niej w r. 1842, tomów 235

Doktor Edwards, legował, idem 315

Nadto Zielnik zamykający do tysiąca roślin, zasuszonych, ułożonych systematycznie w 22 tekach.

Erazm Klefer, typograf wersalski ofiarował wol.

Pomiędzy Rodakami Władysław Ostrowski Marszalek Sejmu, przesłał (w maju 1842) ofiarowane na początek tomów i broszur 206

Nadto odciski medalów polskich z Gabinetu Wiedeńskiego, starannie i umiejętnie rozłożone na 24 tablicach.

Wojewoda Antoni Ostrowski, oprócz dubletów dzieł nowszych swej biblioteki, obdarzył ją poszukiwanemi dziś wydaniami wielu polskich pisarzy.

Joachim Lelewel, dotyczące historyi polskiej rękopisma; posłowie zaś W. Zwierkowski i Ksawery Godebski, znaczną część swych prywatnych zbiorów, na użytek publiczny do niej ofiarowali.

Powolny żądaniu wielu współrodaków, przemilczam tu imiona tych, którzy we własnym sercu postanowili szukać nagrody dobrego czynu, jako tez tych, których dary, z Ks. P. staraniem H. Nakwaskiego, przy końcu r.b. Biblioteka Wersalska otrzyma. Winienem tu oddać świadectwo dobrym dla niej chęciom i jej imieniem oświadczyć wdzięczność Redakcyom Dzienników emigracyjnych (dwie wyjąwszy), które na pierwsze wezwanie, po jednym exemplarzu pism swoich, na własność publiczną bezpłatnie do niej zaofiarowały - w tych rzędzie najpierwszym był Dziennik Narodowy.

$\mathrm{Z}$ tych i tym podobnych źródeł w zbiorze dziś istniejącym znajdują się kosztowne dzieła Duc de Luynes et Debacq - Barona de Bougainville,

${ }^{13} \mathrm{Fr}:$ mairer $=$ mer 
Vancouver, Suchet, Belmas, Memorial du Depôt de la guerre, Michel Chevalier, Boissy d'Anglas, i wiele innych podobnej wartości, o których nie miejsce tu wspominać. Co się tyczy historyi i literatury polskiej i narodów pobratymczych, posiada ona: Polonicae historiae corpus Pistoriusza, Lenhnicha ${ }^{14}$, Puffendorfa, Szafarzyka, Skargi najpierwsze wydanie, Klassykow i Kronikarzy polskich i łacińskich znaczną część, Czackiego, Żywoty sławnych Polaków, Dzienniki z r. 1830-31, słowem: wyłącznie tego przedmiotu dotyczących z górą tysiąc tomów. Możnaż było wzbogacić ją więcej w przeciągu 18 miesięcy, przy nakładach przez pierwszego Opiekuna poniesionych na druki i inne nieuchronne dla niej wydatki?

Jakoż Rodacy w Wersalu zamieszkali, chcący z istniejącego już zbioru korzystać, niedoświadczając najmniejszych trudności, owszem (w czem do ich bezstronnych zeznań niewaham się odwołać) spotykając wszelkie ułatwienia i gotowość służenia im w godzinach oznaczonych, pożytkować z niego nie zaniedbują stosownie do chęci, usposobień i przedmiotu w którym się doskonalą. Nie robię tu tabelli statystycznej czytelnictwa polskiego w Wersalu i obrotu ksiąg wychodzących i wracających do Biblioteki - powiem tylko że w r. 1842, dostarczała ona w przecięciu, co miesiąc po sto z górą woluminów Rodakom ciągle lub chwilowo Wersal zamieszkującym, a była i jest w stanie dostarczyć dwa lub trzy razy więcej, gdyby tego po niej wymagano.

Zobaczmy teraz co o tem wszystkiem powiadają PP. Redaktorowie Dziennika Narodowego? - Oto: iż w całem tem przedsięwzięciu i jego wykonaniu upatrują oni stronę śmieszną - Cóż za dziw? Bo choremu na żółtaczkę, wszystko się żółtem wydaje.

Lurida fiunt quaecunque tuentur arquati. Lucretius ${ }^{15}$.

Gdy jednak oni pierwsi wyrobili w sobie usposobienie do śmieszności i uradzili pożartować z patriotycznych przedsięwzięć i ze skuteczniących je osób; pozwolą też, idąc starym obyczajem, zmierzyć siebie własną piędzią, pomówić z sobą szczerze i po obywatelsku, i nawzajem przed się kilka pytań położyć.

Dlaczego np. Dziennik Narodowy będący miazgą, treścią i essencya zasad, uczuć i rozumu swej redakcyi, jest a priori nieprzyjacielem wszelkich Bibliotek polskich we Francyi założonych lub zakładających się? (patrz Nr. 84.) czy one przegradzają mu w rozwijaniu jego politycznych systematów? I dalej - skąd to monopolizowanie nienawiści ku carowi,

${ }^{14}$ Popr.: Gotfryd Lengnich (1689-1774).

15 Łac.: Z kolei wszystko, co widza ci, którzy maja żóttaczke, wydaje im sie żóttawe... (Titus Lucretius Carus, O naturze rzeczy, tłum. G. Zurek, Warszawa 1994, s. 153, w. 307, 308). 
a przedrzeźnianie wszelkich innych usiłowań na gruncie naukowym lub emigracyjnym opór caryzmowi stawiających? (patrz ciąg artykułów pod tytułem: Kronika) - Miałoż by to być próbą owej tak zwanej royale fantaisie, lub dowodem domyślnej czy rzeczywistej jego narodowości? Czyżby się nie lepiej rymowało z powołaniem Dziennika Narodowego, wzywać, zachęcać autorów współczesnych, do nadsyłania, obdarzania Bibliotek emigracyjnych nowemi utworami - niżeli ten niedostatek onych tu pomiędzy nami, policzać za brak starań lub skąpstwo zarządów bibliotecznych?

Wnioskujemy przez porównania - że np. kto ma brodę - to jeszcze nie dowód, że jest kozłem, mędrcem, żydem lub kacapem - że się temu lub owemu pismu podobało nazwać siebie narodowem, to jeszcze nie dowód, że jest narodowem polskiem. Bystrzejsze oko jednego z dzienników emigracyjnych już to od dawna dostrzegło, i publiczność i PP. Redaktorów o tym uwiadomiło, a przecie - przecie od tej daty, żadnej zmiany i dotykalniejszych dowodów jego polskości jeszcze nikt nie dostrzegł owszem jakieś niemiłą wonią zalatujące dykcye $i$ cytacye - jakieś z zagranicy wywleczone przysłowia, których trzy-czwarte Polaków bez dykcjonarza nie rozumie - jakieś fanatyczne przestrzeganie tytułów i honorów! Skąd to nasuwanie mimochodem wzmianki o Mecenasach i klientach? jest to moi Panowie! Najsłabsza wasza strona, której na szwank wystawiać, nigdy by wam doradzać nie powinien rozsądek. I w istocie rzecz dziwna, że biorąc na się funkcją pedagogów emigracyjnych i monitorów XIX wieku, nie wypełniliście warunku, to jest: poznania samych siebie, a dopiero później i dobrze później, oceniania ludzi i rzeczy - dziś już to wszystkim wiadomo - lippis et tonsoribus nota ${ }^{16}$ - Daleki tu wszakże jestem od śledzenia i przetrząsania wszystkich prywatnych stosunków mówię to tylko w celu wyprowadzenia was z grubego błędu, że i Biblioteka Polska w Wersalu jest uorganizowana na wzór waszego biura redakcyjnego - przyjdźcie, obejrzyjcie - a przekonacie się wespół z Rodakami do niej uczęszczającymi, że ona nie ma Mecenasów nosa zadzierających, ani klientów co miesiąc salaria garnących... że nikt na niej ani bliskich ani dalekich spekulacji nie zakłada, że domysły lub twierdzenia podobne, są obrazą prawdy, zdrowej logiki, i złośliwem lub ograniczonem znieważaniem najczystszych pobudek i najszlachetniejszych usiłowań. Posunęliście dokładność waszych badań, aż do odmiany mojego imienia, przerabiając je na Hieronima - ab uno disce omnes ${ }^{17}$ - mniejsza by jeszcze o to, gdy-

${ }^{16}$ Horacy, Satyry, 1, 7, tu: „wszystkim i bez wyjątku”.

${ }^{17}$ Thum z łac.: po tym jednym [przykładzie ich łajdactwa] sadź ich wszystkich, (Eneida, s, 65). 
by ten nowo administrowany mi Chrzest bez mojej woli i wiedzy, był skutkiem waszej pochyłości do praktyk mistycznych, której z czasu na czas w swym Dzienniku, czarne na biatem, składacie dowody - ale bynajmniej - jest to odwrotna strona tegoż amuletu, który $z$ cicha kaleczy, zabija pobożnie. Jakże, proszę, pogodzić ów duch pozornej dewocyi i pietyzmu ze skandalicznemi anegdotami, które do Dziennika narodowego periodycznie nadsyła Korrespondent z nad Newy? - jak pojąć owe rozprawy subtelno-transcendentalne Pana Pawta Lechińskiego, błąkającego się po jałowem polu sofizmatów, obok teorii Władzy bez podwładnych, Monarchii bez Króla, i tkaniny zasad, które są jednym wielkim historycznym fałszem i politycznym nonsensem? - jak wytłumaczyć na koniec owe wymuszone przyznanie Bibliotece Polskiej w Wersalu, obok przekąsów ku osobie jej pierwszego opiekuna wymierzonych? - Oto, chyba w ten sposób, żeście się wcześnie nie obrachowali z zapasami waszej logiki, lub że decyfrowaliście się nieostrożnie z bezsilną zawiścią i złą wolą szkodzenia Zakładowi w pierwszych latach jego istnienia - albo nareszcie że się was dotyczy powieść o wężu, który chciał ugryźć pilnika ${ }^{18}$. Lecz ja tu nie wchodzę bynajmniej w rozbiór pojęc dziennikarskich, albowiem wolność opinii uznaję za zasadę społeczną - użalam się tylko na spotykane sprzeczności - ubolewam nad niemożnością pogodzenia ich. - Wszakże i to wasze wyrazy i myśli - Zaprawde nie wiemy czy biblioteka na teraz Wersalska zapetni kiedyś mury Uniwersytetu Wileńskiego, wypróżnione przez cara - i proszę uważać, że to mówią politycy mający pretensją do głębokich widzeń teraźniejszości, do bystrego objęcia widoków, celów i środków każdego czynu!! Naprzód nie razem Kraków zbudowano; a potem, nie idzie tu o materyalne zapełnienie wypróżnionych rabunkiem sal bibliotecznych - przypuśćmy, że tu idzie choćby o wniesienie do nich pamiątki na jaką ubóstwo tułacze zdobyć się może - to i w takim razie, biegli w cytacyach ewangelicznych, wiedzieć przecie powinni, że grosz wdowi, cichem i czystem sercem ofiarowany, wyższą miewa cenę, niż bogate a przechwałek pełne dary Faryzeuszów... - Dalej idąc waszym torem, z tej jednej wątpliwości mógłby ktoś wywnioskować, że może nawet wątpicie o świetniejszej przyszłości Akademii Wileńskiej a następnie że nie macie żywej wiary w przyszłe zmartwychwstanie Polski - na cóż więc i tę stronę waszych przenikliwości niepotrzebnie na szwank podawać? Zresztą w Dzienniku nazywającym się Narodowym na serdeczniejsze wspomnienie zasługiwała Akademia Wileńska, owa sta-

${ }^{18}$ Z wiersza Pseudo Józefa Bielawskiego, Wiersz na Poetę Wegierskiego, http://www.pbi. edu.pl/book_reader.php? $\mathrm{p}=13989 \& s=$ [4 XII 2012]. 
rożytna świątynia światła krajowego, do której w ostatnich czasach uboga, demokratyczna i patriotyzmu pełna młodzież z różnych prowincji Polski gromadząca się, piechota po nauki chodziła, nie zazdroszcząc bynajmniej tym, którzy drążkami ${ }^{19}$ po nie jeździli - Wprawdzie niedzisiejsze to czasy - upłynione już dzieje - a przecie rzeczywistej przewagi drugich nad pierwszymi, ani przeszłe nad teraźniejsze niewykazany lata...

Powiedzcie też otwarcie, czy nie trafniej by było, zamiast wysnuwania bajecznych mytchów i tworzenia podejrzanej natury przysłowiów kosztem Biblioteki Polskiej w Wersalu, ażebyście raczej z ręką na sercu opowiedzieli przeobrażania się waszego dziennika, wraz z towarzyszącemi mu mythami i legendami? Byłaby to rzetelna przysługa dla przyszłych antykwariuszów i bibliografów, którym bez takiej pomocy, trudno, a raczej niepodobna będzie rozwikłać plątaniny zaszłe przy zmianach jego zasad, teorii, i tym podobnych własności. Z tych autentycznych podań nie omieszkałby skorzystać najpierw jej katalog Biblioteki Polskiej w Wersalu, i dla zwrócenia zasłużonej uwagi na pisma wasze, krzyżykiem je oznaczyć. Katalog ten, według przyjętego zobowiązania, ogłoszonym będzie, skoro oczekiwane dary w księgach i fundusze na pokrycie kosztów druku, nadejdą do Biblioteki - dziś ubóstwo materialne nie hańbi jej - wyznanie jego, nie poniża - spodziewa się i ona mieć swych dobrodziejów, i jako Instytucya dobro krajowe mająca na celu, niewątpliwie w nadziei zawiedzioną nie będzie - a jakkolwiek dla niechętnych lub zazdrosnych jest już sola w oku, przestać-li ma służyć dobrej sprawie i rozpaczać dlatego, iż PP Redaktorowie Dziennika narodowego są na nią niełaskawi?... W ten sposób, może niewiedząc o tem czyliż nie stanęliście, moi Panowie! Obok wieśniaka Horacego, który czekał nad brzegiem, nim przepłynie rzeka;

At ille (amnis) labitur et labetur in omne volubilis aevum... ${ }^{20}$

Jeśli tych kilka pytań uznajecie za nieprawdziwe lub bezzasadne - jeśli macie co zgodnego z prawda do odpowiedzenia na nie - kolumny waszego dziennika są wam otwarte - odpiszcie.

Wersal, d. 22 Listopada 1842.

Hipolit Klimaszewski

Konserwator Bibl. Pol. w Wersalu.

${ }^{19}$ Bliżej nieokreślony rodzaj powozu konnego.

${ }^{20} \mathrm{Z}$ Listów Horacego, tłum z łac.: A fale plyna i plyna i plynąc będa, choć wieki mina. 